\title{
"M-Auto" The Augmented Reality-Based (AR) Learning Media Application for the Finite-State Automata (FA) Reduction Subject of Language and Automata Theory Courses
}

\author{
Dimas Prasetyo Buseria , F Ti Ayyu Sayyidul Laily a , Fajar Ananda Saputra a , \\ Imro'aturrozaniyah ${ }^{a}$, Kartika Candra Kirana ${ }^{b^{*}}$ \\ ${ }^{a}$ Computer Science Department Students, Faculty of Technique, State University of Malang, \\ Malang, 65145, Indonesia \\ ${ }^{b}$ Computer Science Department Teacher, Faculty of Technique, State University of Malang, \\ Malang, 65145, Indonesia Phone: +62 813-3494-5635 \\ E-mail: kartika.candra.ft@um.ac.id, fajarananda29@gmail.com,buseridimas@gmail.com, \\ eftiayyu@gmail.com,rozaniyahimroatur1999@gmail.com
}

\begin{abstract}
A proper learning process should contain innovative, amusing, challenging, and motivating aspects. It should be able to provide an opportunity for the students to develop their creativity and independency based on their interest and talent. Less interesting and tedious classroom learning activity indicates the factor of the students' learning interest degradation, for example as in the language and automata theory and finite-state automata reduction subject. The current research aims to aid language and automata theory in learning activity to be easier to acquire. With the Augmented Reality-based learning media, the researcher hopes that the students can develop their understanding and their interest in a learning activity, especially for finite-state automata subject. The subject of the current research is the Augmented Reality-based application as the learning media for language and automata theory and finite-state automata material. The researcher employs several research methodologies such as literature review, library research, and questionnaire to support the current research. The application is designed according to system development that consists of problem identification, appropriateness study, need analysis, concept designing, content designing, script designing, graphic designing, system production, and system examination. The result of the current research is the AR-based learning media application for the finite-state automata reduction subject of language and automata theory.
\end{abstract}

Keywords: Learning Media, Finite-State Automata Reduction, Augmented Reality 


\section{INTRODUCTION}

The rapid development of today's science and technology causes the advancement of several aspects of human life such as communication, social, economy, politics, culture, and education. However, the utilization of science and technology still does not meet the expectation for Indonesia's upturn. This kind of circumstance gives a negative impact on national development. Properly speaking, technology holds an important role in delivering information, whether it is in the form of texts, images, or even voices to the users all over the world. The current technology development still not well-utilized. Moreover, it is still way too far to realize the full application as the supporting media for national development. (Latifah \& Handayaningsih, 2014)

One of the examples is the education. Education is an important asset for the nation to achieve the advancement of the citizens' productivity. In this case, Indonesia's educational progress still requires a lot of improvement. The education system is still insufficient in terms of providing the proper understanding for the students. They still apply the classic and monotonous system while doing several learning activities. A low learning performance often indicated by the learning problem in material comprehension. This kind of indication is caused by ineffective learning habit and students are not feeling motivated to follow the learning activity during the class. (Latifah \& Handayaningsih, 2014)

Technology utilization for the educational purpose in Indonesia is still improper. One of the factors that causes the improper utilization is the facility which still does not meet the requirement. However, there are several teachers that already employs technology for the educational purposes. There are a lot of possibility to ease the learning material transference and make it easier to be acquired by someone. One of those possibility is using the supporting tools or learning media. According to a research, the human's sense ability of each person is not similar. In a learning process, most of the students use $83 \%$ sight, $2,5 \%$ taste, 3,5\% touch, $11 \%$ hearing, and 1\% smell. (Wiroatmojo \& Sasonohardjo, 2002). based on the previous data, it can be inferred that an efficient learning material transference can be well-optimized if a learning process utilizes all of the human's five senses at once.

Learning media is a tool that can be utilized as a knowledge transference and also stimulates students' sense, mind, motivation, and attention to support their learning process. (Sumiati dan Asra, 2012). Today's advancement of technology generates some inventions. One of those inventions is Augmented Reality. Augmented Reality (AR) is a part of technology advancement that is commonly utilized as a learning media nowadays. 
Augmented Reality is, somehow, helpful for enhancing the experience of learning, especially for the interactive learning media. Moreover, the Augmented Reality-based learning media can increase the students' interest in learning. The combination between reality and virtual world in a single touch makes the learning activity can be more interesting for the students. The utilization of Augmented Reality as a learning media can help the students to stimulate their mindset to be a critical thinking towards a certain problem and daily event that happens around the students. Augmented Reality-based learning media helps students to have their own learning activity even with no teacher is possible. Students can have their own learning activity, anytime anywhere they want. (Mustaqim \& Kumiawan, 2016).

Language and automata theory is one of the components of computer science study field. It is a fundamental aspect of computation system. Language and automata theory is a one of the compulsory subjects of computer science department that should be taken in order to achieve a bachelor degree. According to the acquired data from the questionnaire that have been distributed to the sample of computer science students in State University of Malang academic year 2018, it can be calculated and inferred that $40.9 \%$ of students still encountering a problem in understanding the sub material of finite-state automata (FA) which is called state reduction and the rest is the other sub materials of language and automata theory. The factor is because of the learning system that is less interactive.

As one of the learning media, the writer picks out the Augmented Reality to help out the students' learning activity in language and automata theory courses, especially the finitestate automata (FA) reduction subject. The utilization of Augmented Reality as a learning media can encourage the students to stimulate their mindset to be a critical thinking towards a certain problem and daily event that happens around the students and helps out the students to visualize abstract concept of understanding and a structure of a certain object model. Based on the problem that have been mentioned previously, it is necessary for the writer to create an innovation to support the interactive learning media, especially for language and automata theory course. In accordance of the writer's urgency to create an innovation, the writer have decided "(M-auto) The Augmented Reality-Based (AR) Learning Media Application for the Finite-State Automata (FA) Reduction Subject of Language and Automata Theory Courses" as the title of the innovation. That is an interactive learning media that discuss about language and automata theory, especially for finite-state automata reduction subject. 


\section{METHODOLOGY}

The current research is conducted with several research methodologies in order to aid the data completeness. Here is the some methodologies that is employed for the research:

\subsection{Literature Review}

The writer employs literature review methodology in a way that the writer reads and explores the available reading material from the various sources. The writer tries to read and investigate the sources such as books, magazines, websites, articles, and other available documents. Once the data is already gathered, the writer tries to make a certain understanding about the topic. And the last thing is making a conclusion from the main points that have already been studied previously. The writer studied about the problem of learning activity in language and automata theory course, especially finite-state automata (FSA) reduction subject.

\subsection{User's Need Analyisis}

In the current research, the utilized method in order to gather the data from the respondents is the questionnaire. The writer distributes the questionnaire to all of the computer science students of State University of Malang academic year 2018. However, the amount of data that have been recorded is only 22 students. The questionnaire that have been already distributed contains some question about the students understanding towards language and automata theory course, especially finite-state automata reduction subject. The question is created in order to comprehend the responses towards the AR-based learning media for language and automata theory courses, especially finite-state automata reduction subject.

\subsection{Design}

After conducting a literature review, the next step is designing the Language and Automata Theory Learning Media with the subject matter of FSA State Reduction at the stage of mockup application manufacture and animated picture of state reduction material based on Augmented Reality (AR).

\subsection{Data Analysis}

After the data is collected, then it is analyzed using descriptive analysis. Descriptive analysis is an analysis technique used to analyze data by describing the data that has been collected without any intention of generalizing from the results of the research (Sora N, 2015). In this research, descriptive analysis applies frequency distribution in the form of tables and graphs.

\subsection{Writing instrument}


The instrument of this writing is in the form of data, both hard copy dan soft copy that is obtained from various media such as internet, magazines, newspapers, journals, books, and other instruments that support information about student problems during the teaching and learning activities in the Theory of Language and Automata.

\section{RESULTS AND DISSCUSSION}

\subsection{Main Menu Page Display}

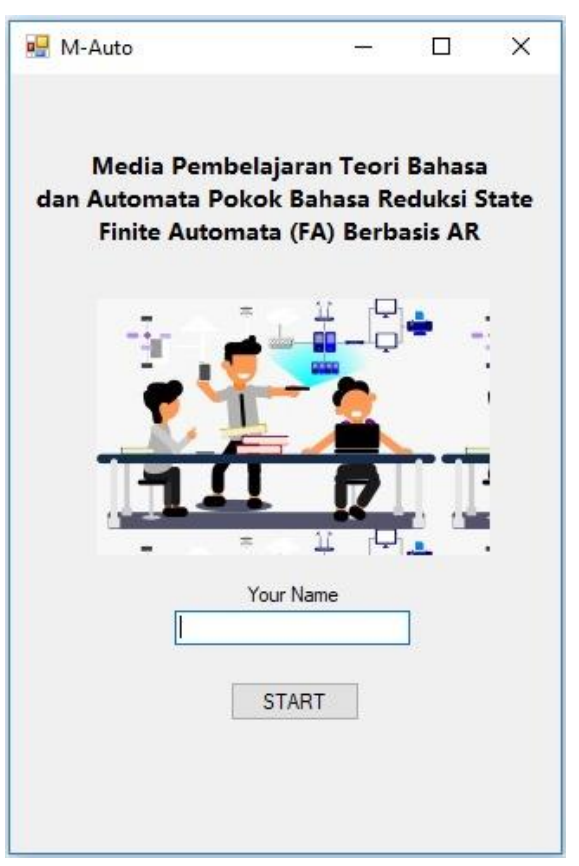

Image 6. Main Menu Page Display Source: Private document

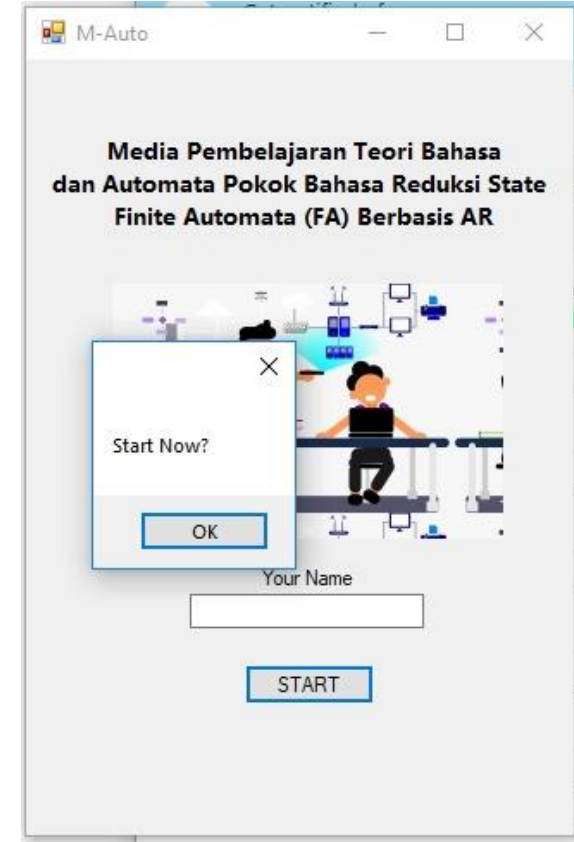

Image 7. Main Menu Page Display Source: Private document

In the main menu or main display, a textbox is provided to input the username and start button to run the program. If you click start, the message box will appear with a text with an instruction either running the program now or not. This menu utilizes the concepts of inheritance and assessors in registering their names. Each display contains several features such as close, minimize and restore down. 


\subsection{Material Menu Page Display}

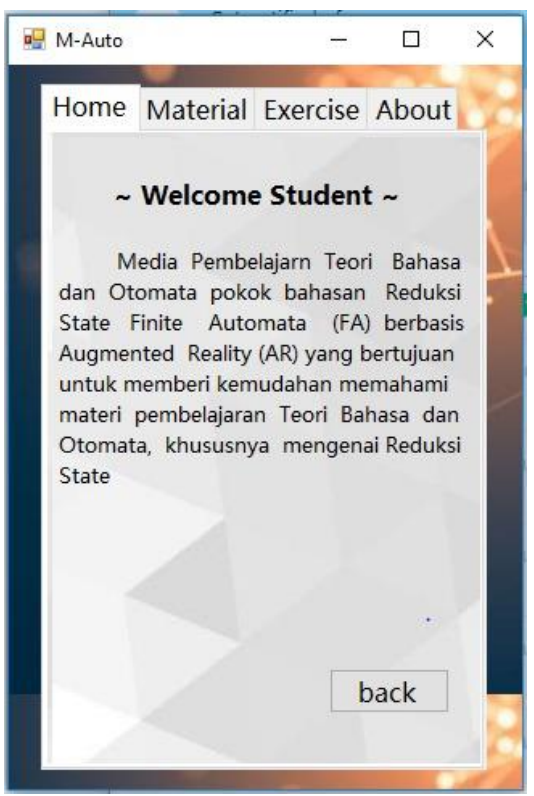

Image 8. Home Page Display

Source: Private document

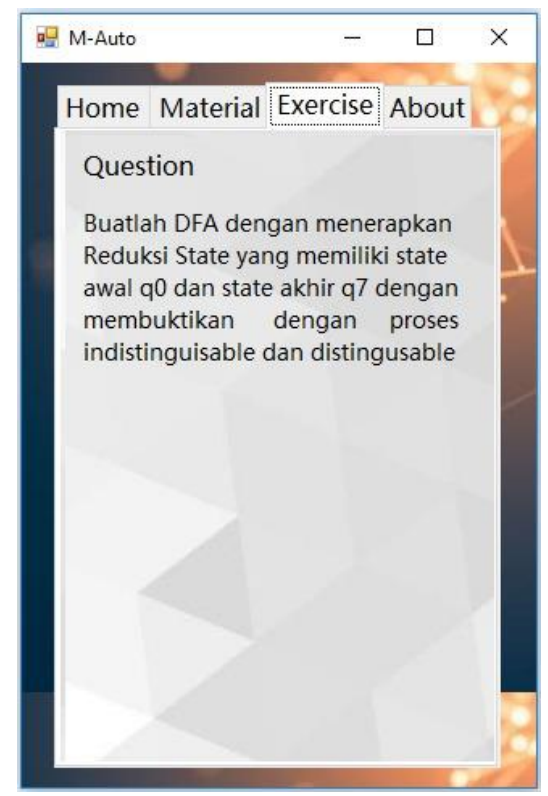

Image 10. Exercise Page Display Source: Private document

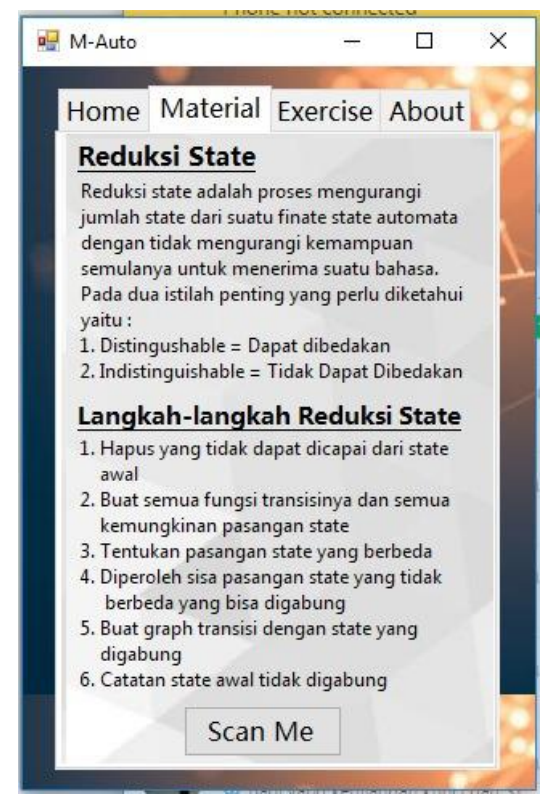

Image 9. Material Page Display

Source: Private document

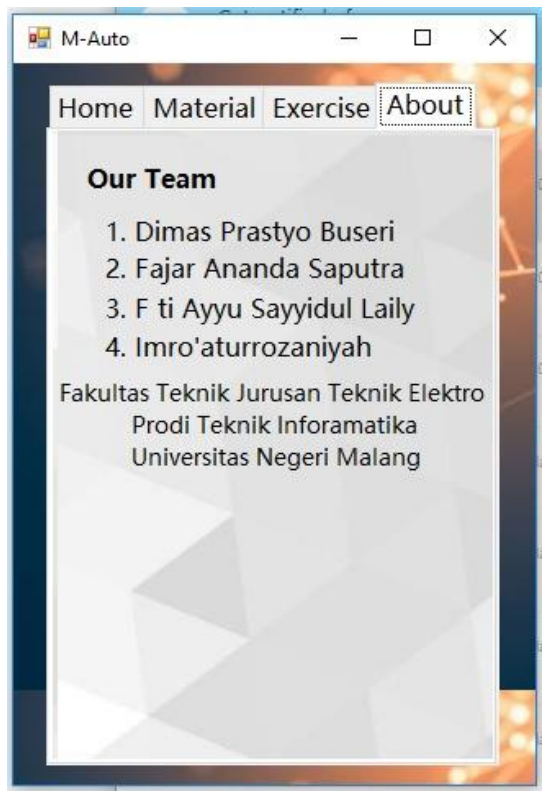

Image 11. About Page Display

Source: Private document

The menu of page display consists of home, material, exercise and about. The home display contains an explanation of the application, the material display covers the subject matter of the reduction state of language and automata theory and contains "scan me" button to lead the user to use augmented reality of the language and automata theory, the exercise display includes the questions that must be done by the user, and on the about menu page comprises the application creators information. 


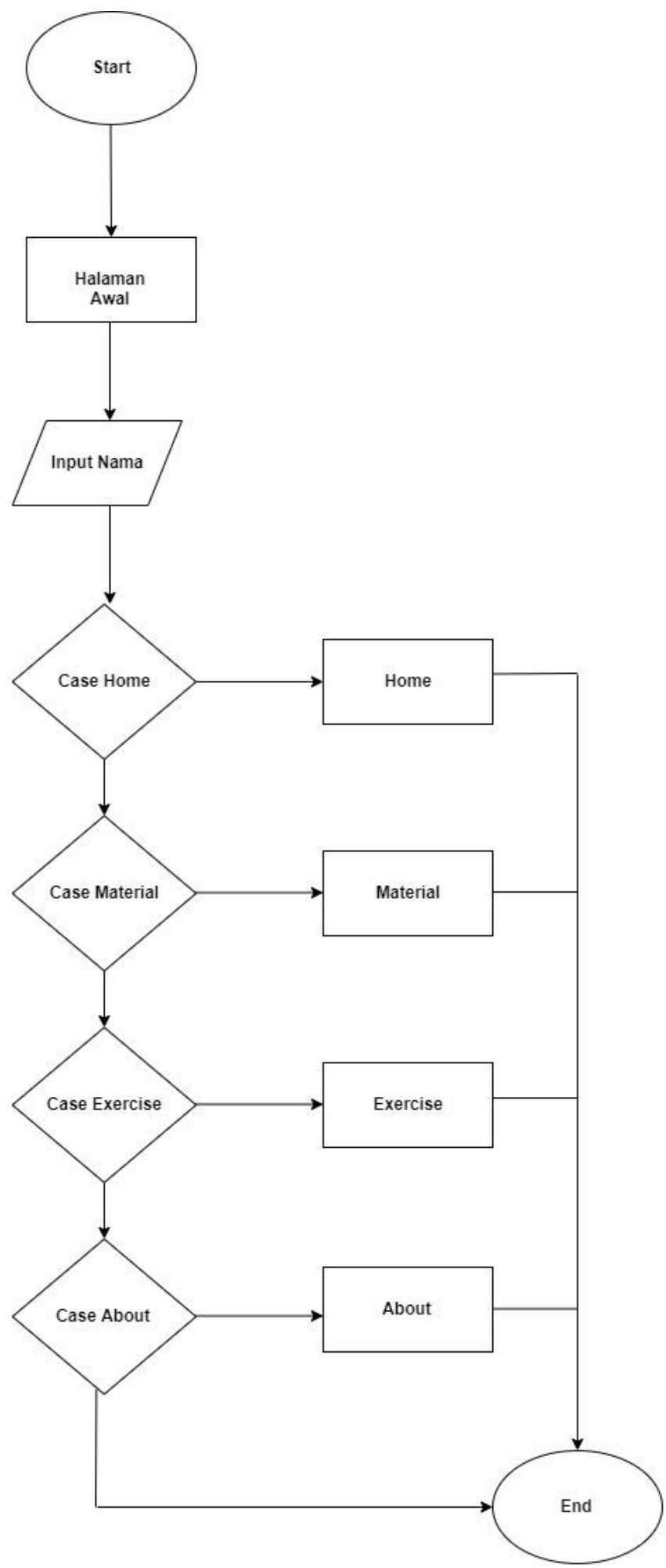

Image 12. Flowchart System

Source: Private document

\subsection{Augmented Reality (AR) on the M-Auto Application}

According to Muntahanah et al. (2017) Augmented Reality (AR) is one of the technological developments in this era. Augmented Reality (AR), is a technology that combines two-dimensional and three-dimensional virtual objects into a real threedimensional environment and then projecting these virtual objects in real time. AR can be 
displayed on various devices such as glasses, screens, mobile phone and so forth. A few data in the form of videos, images, animations, and 3D models need to be used for making the device working properly, so that people can see the results in artificial and natural light.

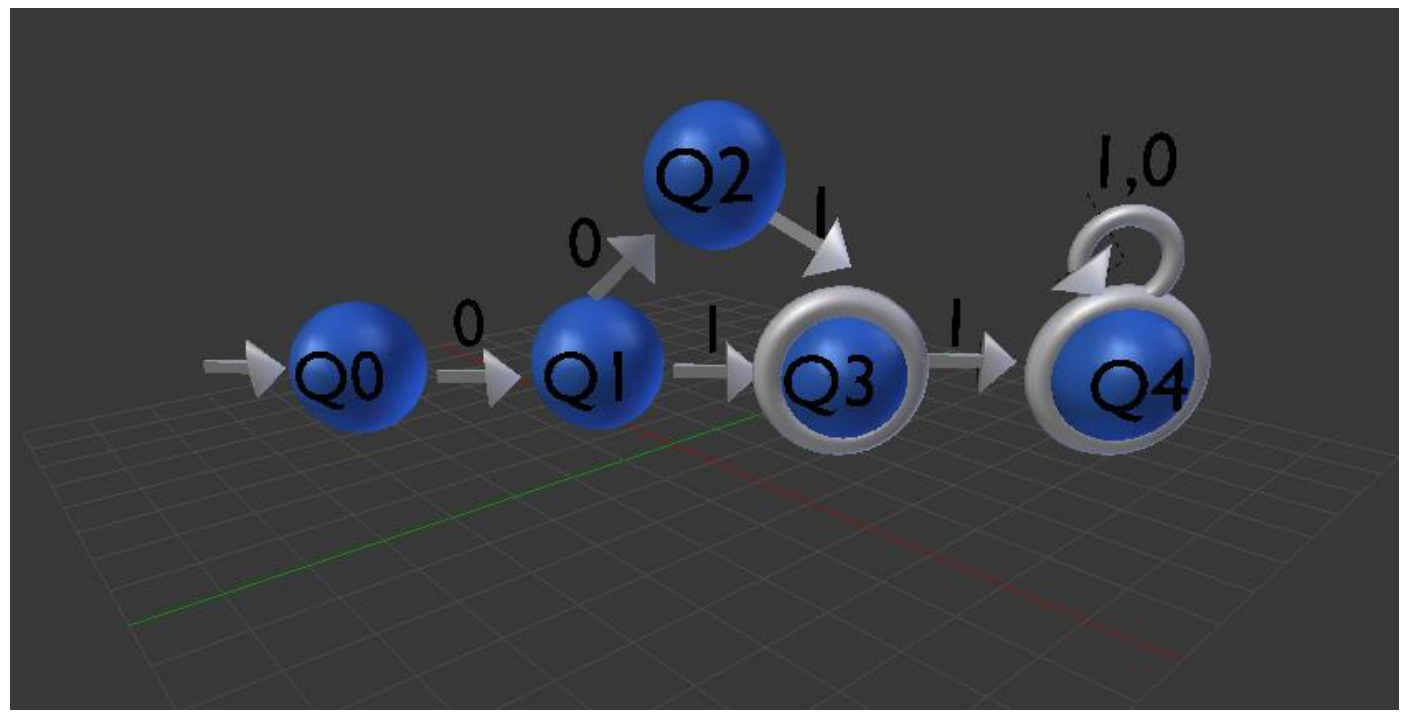

Image 13. Augmented Reality-based State Reduction Material in the M-Auto Application Source : Personal Document

Augmented Reality which is applied by researcher about leaning theory of language and automata especially on material reduction state. Picture 4 is an example of DFA (Deterministic Finite Automata) which will be reduced the state. The steps in reducing the state of DFA (Deterministic Finite Automata) consist of several steps, as follow below:

Making a transition table,

$$
\begin{aligned}
& \mathrm{Q}=\{\mathrm{q} 0, \mathrm{q} 1, \mathrm{q} 2, \mathrm{q} 3, \mathrm{q} 4\} \\
& \sum=\{0,1\} \\
& \mathrm{S}=\mathrm{q} 0 \\
& \mathrm{~F}=\{\mathrm{q} 4\}
\end{aligned}
$$

Table 1. Transition Table

\begin{tabular}{|l|l|l|}
\hline$\square$ & $\mathbf{0}$ & $\mathbf{1}$ \\
\hline $\mathbf{q 0}$ & $\mathrm{q} 1$ & $\varnothing$ \\
\hline $\mathbf{q 1}$ & $\mathrm{q} 2$ & $\mathrm{q} 3$ \\
\hline $\mathbf{q 2}$ & $\varnothing$ & $\mathrm{q} 3$ \\
\hline $\mathbf{q 3}$ & $\varnothing$ & $\mathrm{q} 4$ \\
\hline $\mathbf{q 4}$ & $\mathrm{q} 4$ & $\mathrm{q} 4$ \\
\hline
\end{tabular}

To analyze each of states

1. Identify each possible combination of states:

$(\mathrm{q} 0, \mathrm{q} 1)$ 
$(\mathrm{q} 0, \mathrm{q} 2)$

$(\mathrm{q} 0, \mathrm{q} 3)$

$(\mathrm{q} 0, \mathrm{q} 4)$

$(\mathrm{q} 1, \mathrm{q} 2)$

$(\mathrm{q} 1, \mathrm{q} 3)$

$(\mathrm{q} 1, \mathrm{q} 4)$

$(\mathrm{q} 2, \mathrm{q} 3)$

$(\mathrm{q} 2, \mathrm{q} 4)$

$(\mathrm{q} 3, \mathrm{q} 4)$

2. State in pairs with final state is distinguishable states

$(\mathrm{q} 0, \mathrm{q} 1)$

$(\mathrm{q} 0, \mathrm{q} 2)$

(q0, q3) : distinguishable

(q0, q4) : distinguishable

$(\mathrm{q} 1, \mathrm{q} 2)$

(q1, q3) : distinguishable

(q1, q4) : distinguishable

(q2, q3) : distinguishable

(q2, q4): distinguishable

$(\mathrm{q} 3, \mathrm{q} 4)$ : distinguishable

3. For other pairs of states when each of states get the same input, so if one state reaches final state while the others are not reachable final states then it is called distinguishable.

For $(\mathrm{q} 0, \mathrm{q} 1)$ :

$\square(\mathrm{q} 0,0)=\mathrm{q} 1$

$\square(\mathrm{q} 1,0)=\mathrm{q} 2$

$\square(\mathrm{q} 0,1)=$

$\square(\mathrm{q} 1,1)=\mathrm{q} 3$

Then (q0, q1 ) : distinguishable 
For (q0, q2) :

$$
\begin{aligned}
& \square(\mathrm{q} 0,0)=\mathrm{q} 1 \\
& \square(\mathrm{q} 2,0)= \\
& \square(\mathrm{q} 0,1)= \\
& \square(\mathrm{q} 2,1)=\mathrm{q} 3
\end{aligned}
$$

Then (q0, $\mathrm{q} 2)$ : distinguishable

$$
\begin{aligned}
& \text { For }(\mathrm{q} 1, \mathrm{q} 2): \\
& \square(\mathrm{q} 1,0)=\mathrm{q} 2 \\
& \square(\mathrm{q} 2,0)= \\
& \square(\mathrm{q} 1,1)=\mathrm{q} 3 \\
& \square(\mathrm{q} 2,1)=\mathrm{q} 3
\end{aligned}
$$

Then (q1, q2 ) : indistinguishable

4. The following pairs of states are obtained:

$$
(\mathrm{q} 0, \mathrm{q} 1) \text { : distinguishable }
$$

(q0, q2) : distinguishable

(q0, q3) : distinguishable

(q0, q4) : distinguishable

(q1, q2) : indistinguishable

(q1, q3) : distinguishable

(q1, q4) : distinguishable

(q2, q3) : distinguishable

(q2, q4) : distinguishable

$(\mathrm{q} 3, \mathrm{q} 4)$ : distinguishable

5. Since, $\mathrm{q} 1$ is indistinguishable with $\mathrm{q} 2$, it can be stated that $\mathrm{q} 1$ and $\mathrm{q} 2$ are indistinguishable and can be made as one state. So that the final state reduction can be described as shown in Figure 5. 


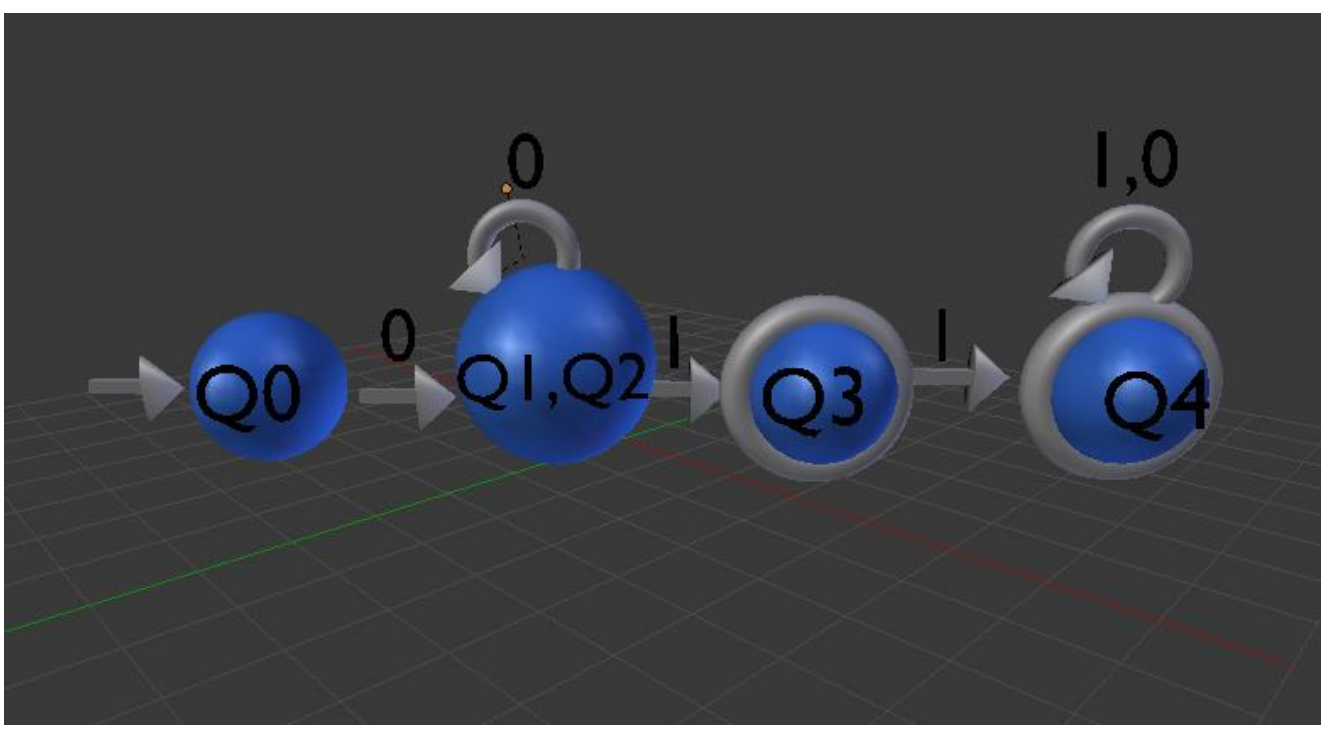

Image 14. Augmented Reality Based State Reduction Results in the M-Auto application Source: Private document

\subsection{Survey Analysis}

The respondents are 22 undergraduate students of computer science department, State University of Malang academic year 2018. In this research, the writer explains the percentage of language and automata theory courses material understanding at State University of Malang.

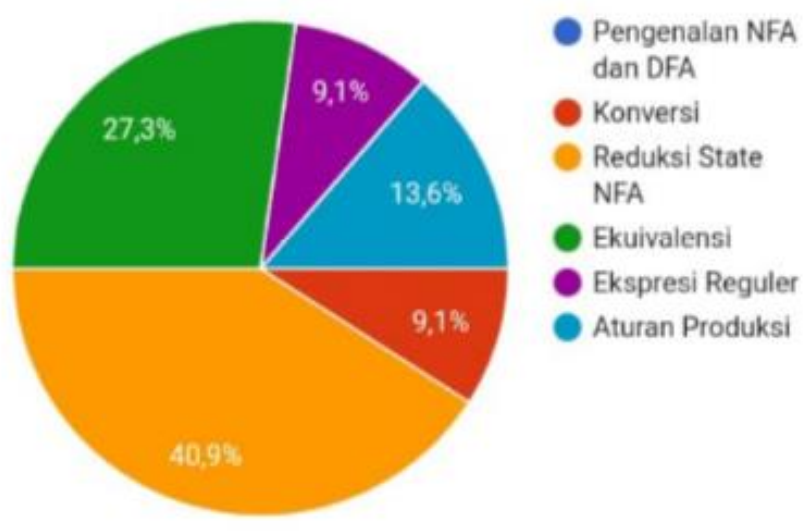

Image 15. Language and automata courses survey analysis Source: Private Document

Percentage of respondents regarding the term of language and automata courses indicates $40.9 \%$ of respondents still lack of understanding the state reduction material. In this case, it is necessary to create an interactive learning media so that the students can understand the material easier. 


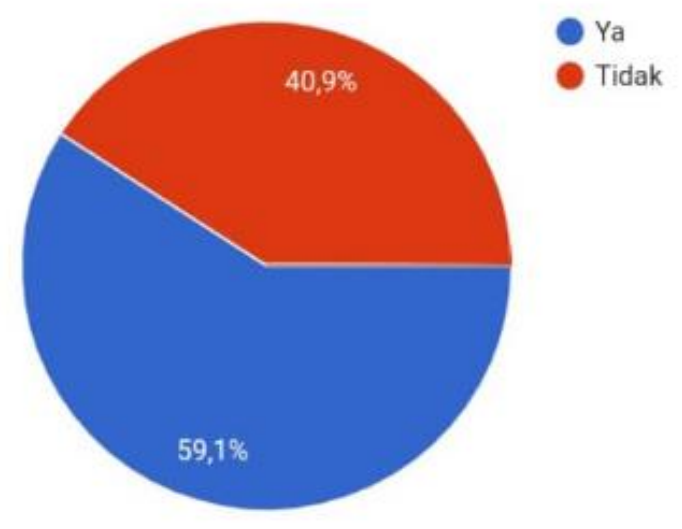

Image 16. State Reduction Understanding Survey Source: Private Document

Percentage of respondents regarding the level of understanding the term of language and state reduction automata material shows $59.1 \%$ of 22 respondents found some difficulties in understanding the material because of the complicated steps and the needs of accuracy in the process.

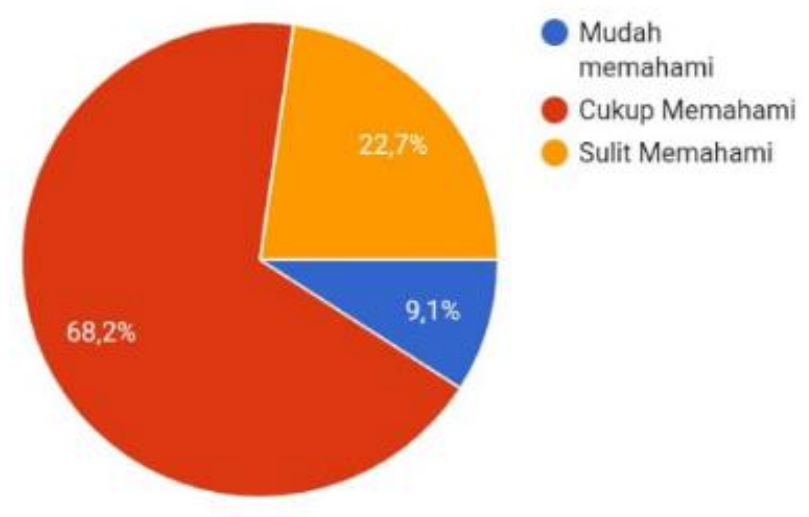

Image 17. Survey of Understanding the Level of State Reduction in Terms of Learning Media Source: Private Document

In this survey, the level of state reduction understanding of in terms of learning media are $68.2 \%$ of respondents elucidate that it is sufficient to understand the state reduction material, $9.1 \%$ of respondents elucidate that state reduction material is easy to understand and $22.7 \%$ of respondents elucidate that it is difficult to understand the material . In this case, a solution is needed to further improvement regarding the level of students' understanding in learning language and automata, exceedingly in the sub-state reduction 
material. Furthermore, utilizing an interactive media could increase the level of students' understanding, for instance is by enhancing augmented reality technology.

\section{CLOSING}

Based on the results of the study, it was found that the average questionnaire of informatics engineering students at Negeri Malang university in 2018 had difficulty in understanding language theory and automata courses around $40.9 \%$ in the state reduction material. Calculated from the level of student's understanding in the material that students who have difficulty understanding as much as $59.1 \%$. From the survey, most of students still do not really understand the state reduction material. Factors that influence are about the terms of instructional media because according to the survey, as many as $68.2 \%$ of students that understand enough with simple learning media, $22.7 \%$ of students find it difficult to understand and only $9.1 \%$ of students easily understand the material. From this, it can be concluded that the learning media, especially in the theory of language and automata courses which need to have interactive learning media. One of them is applying augmented reality in learning language theory and automata.

This research applies that the concept of object-oriented programming (OOP) consisting of Inheritance, Polymorphism, Encapsulation, abstract, and mutator assessors. However, the material has not been written in journals, so as further research by the application of OOP will be written in a next journal.

\section{REFERENCES}

[1]. Mustaqim, Ilmawan \& Kurniawan, Nanang. 2004. Teori Bahasa, Otomata, dan Komputasi serta terapannya. Bandung: Informatika.

[2]. Kustiawan, Iwan. 2009. Perancangan Media Pembelajaran Berbasis Augmented Reality. Bandung: Teknik Elektro UPI

[3]. Latifah, Lulu \& Handayaningsih, Sri. 2014. Media Pembelajaran Teori Bahasa dan Otomata Pokok Bahasan Finite Automata (FA) berbasis Augmented Reality (AR). Yogyakarta: Universitas Ahmad Dahlan.

[4]. Muntahanah; Toyib, Rozali; Ansyori, Miko. 2017. Penerapan Teknologi Augmented Reality pada Katalog Rumah Berbasis Android (Studi Kasus PT. Jashando Han Saputra. Jurnal Pseudocode, 4(1), 81-89.

[5]. Sora N. 2015. Ketahui Pengertian Analisis Data dan Tujuannya, (Online), (http://www.pengertianku.net/2015/09/pengertian-analisis-data-dantujuannya.html) 
[6]. Sumiati \& Asra. 2012. Metode Pembelajaran. Bandung: CV Wacana Prima

[7]. Satria, Wantah \& Handayaningsih, Sri. 2013. Pembuatan Media Pembelajaran Untuk Proses Konversi pada Finite Automata Berbasis Multimedia. Yogyakarta: Universitas Ahmad Dahlan.

[8]. Wiroatmodjo dan Sasonohardjo. 2002. Media Pembelajaran (Bahan Ajar Diklat Kewidyaiswaraan). Jakarta: Lembaga Administrasi Negara Republik Indonesia. 